Sains Malaysiana 47(11)(2018): 2757-2767

http://dx.doi.org/10.17576/jsm-2018-4711-18

\title{
Strides towards the Realization of Cure for Cartilage Defects and Osteoarthritis: The Limitation and Regulatory Challenges
}

\author{
(Kemajuan ke Arah Merealisasikan Perubatan bagi Kecacatan Tulang Rawan
}

dan Osteoartitis: Had dan Cabaran Pengawalan)

Ude Chinedu Cletus, AZIZI Miskon \& RuszymaH BT Hu IDRUS*

\begin{abstract}
Despite remarkable mechanical durability and strength, hyaline cartilage has very limited capacity for self-repair when injured and over time, may degenerate to osteoarthritis. We evaluated the most significant mile stones attained, in the pursuit of cure for cartilage defects and osteoarthritis. The basic treatment options include: Natural or physical therapy, medications, nutritional supplements, nutriceuticals and chondroprotective agents. Next are repairs and replacements, which include surgical procedures: Debridement/chondroplasty, microfracturing, mosaicplasty, periosteum transplantation, osteochondral autografting and allografting, high tibial osteotomy and total knee arthroplasty. But, current trend has shifted from repair, replacement, to most recently regeneration. Regenerations include the cell and gene therapies. While cell therapy involves the use of cells isolated from different tissues to cause regeneration of cartilage; gene therapy involves the selection of appropriate gene and optimal vector to incorporate cDNA. There has been much positivity reported with big animal models, which has led to several ongoing clinical trials. Translations of these findings hold high promises, though not without inherent regulatory hurdles. Considering the initial success rates, there are increasing hopes of realizing these treatments from bench to bedsides. Significant improvements in the treatment of cartilage degenerations and osteoarthritis have been made so far, but no gold standard delineated.
\end{abstract}

Keywords: Cartilage defects; cell therapy; osteoarthritis; tissue engineering

ABSTRAK

Meskipun mempunyai kekuatan dan ketahanan mekanik yang luar biasa, rawan hialin mempunyai kapasiti yang terhad untuk memulih sendiri apabila tercedera serta akan merosot kepada osteoartitis. Penilaian bagi langkah paling berkesan telah dilakukan dalam usaha mengubati kecacatan rawan dan osteoartitis. Rawatan asas termasuk: terapi semula jadi atau fizikal, ubat-ubatan, pemakanan tambahan, nutriseutis dan agen kondropelindung. Selepas itu adalah pembaikan dan penggantian melalui pembedahan: Debridemen/kondroplasti, mikropatah, mozaikplasti, pemindahan periosteum, autocantuman dan alocantuman osteokondral, osteotomi tibial tinggi dan jumlah artroplasti lutut. Namun, trend terbaru beralih daripada pembaikan dan penggantian kepada penjanaan semula. Penjanaan semula termasuk terapi sel dan gen. Terapi sel melibatkan penggunaan sel-sel yang diasingkan daripada tisu yang berbeza untuk penjanaan semula rawan manakala terapi gen pula melibatkan pemilihan gen yang sesuai dan vektor optimum untuk menggabungkan cDNA. Banyak laporan positif telah diperoleh dengan menggunakan model haiwan yang besar seterusnya menggalakkan beberapa ujian klinikal secara berterusan. Penemuan ini menunjukkan potensi yang tinggi, meskipun terdapat cabaran kawalan yang perlu dihadapi. Berdasarkan kadar kejayaan awal, rawatan ini perlu dipertimbangkan ke tahap yang lebih tinggi. Kemajuan yang ketara dalam rawatan penjanaan semula rawan dan osteoartitis telah dapat dilihat setakat ini, tetapi tidak ada piawaian emas yang ditandakan.

Kata kunci: Kecacatan rawan; kejuruteraan tisu; osteoartitis; terapi sel

\section{INTRODUCTION}

Osteoarthritis (OA), considered as one of the leading cause of disability worldwide is a painful progressive condition that presents itself as the thinning of articular cartilage, inflammation, sclerosis and osteophytes formation. In severe form, synovial irritations, bone remodeling and spur bones result in uneven joint surfaces thus accelerating joint degeneration. The disease is classified, not only as a cartilage disease, but rather pathology of the whole joint tissues (McAdams et al. 2010; Scott et al. 2014). Primary osteoarthritis is idiopathic and develops in previously undamaged joints; while the secondary, is caused by well predisposing factors. For instance, acute injury to joint, the low inherent replication capacity of chondrocytes, the incomplete articular cartilage repair and further repetitive loading of the injured cartilage predisposes to cellular degeneration with accumulation of degradative enzymes (Al Faqeh et al. 2012; Ding et al. 2006; Ude et al. 2015, 2014).

Considering the fact that the primary risk factor of $\mathrm{OA}$ is age, collagen type 2 , proteoglycan and glycosylation 
of end products undergoes structural modification which alters the biomechanical properties of extracellular matrix; leading to loss in the ability of cartilage adaption to mechanical stress/loading (Freitag et al. 2016). As chondrocytes ages, free radicals (reactive oxygen species $\left(\mathrm{O}_{2}+, \mathrm{O}_{2}^{-}\right)$, Nitric Oxide (NO) and NO synthase) are synthesized; induced by either mechanical or biological stressors. Reactive oxygen radicals lead to senescence, while NO and NO synthase lead to apoptosis. Cell senescence triggers the up regulation of inflammatory cytokines, such as Tumor Necrosis Factor Alpha (TN $\alpha)$, Matrix Metallopeptidase-13 (MMP-13) and Interleukin-1 (IL-1). These are potent drivers of cartilage degradation. They stimulate other pro-inflammatory factors such as Interleukin-6 and 8, leukotriene inhibiting factor, proteases, neuropeptides, Matrix Metallopeptidase-7 (MMP-7) and prostaglandin E2 (PGE2). NO and NO Synthase inhibit proteoglycan synthesis and the effect of insulin-like growth factor-1 (IGF-1) on chondrocytes; playing a role in chondrocyte apoptosis. Both the senescence and apoptosis activities increase catabolisis of collagen II and extracellular matrix degradation (Freitag et al. 2016).

Pro-inflammatory mediators from synovium, cytotoxic M1 macrophages also down-regulates chondrogenic gene expression of mesenchymal stem cells. Evidence exist, linking the depletion in number of local population of MSCs, their reduced proliferation and differentiation to progressive degenerative OA (Wayne Lee \& Wang 2017). Other factors include: hereditary (sex), congenital and developmental disorders, acquired activities (occupational/repetitive activities, sports, traumatic postures), local mechanical factors (high body mass index, obesity, muscle weakness, alignment, mechanical instability), behavioral and hormonal factors (smoking, oestrogen), local osseous factor (bone marrow lesion, bone mineral density), infections, vascular and avascular necrosis (haemarthrosis), connective tissue disorder (Ehlerse Danlos syndrome, Marfan syndrome) neuropathic, diabetes mellitus and Charcot syndrome, constitutes the major predisposing factor to the disease (Kong et al. 2017).

The symptomatic occurrence of OA has been associated with $10 \%$ of males and $18 \%$ of females over 45 years; with a radiological prevalence of about $80 \%$ in people above 65 years with almost everyone showing some symptoms by the age of 70 (Al Faqeh et al. 2012). Generally, it is viewed that OA, occurs when there exists a shift between catabolic and anabolic pathways as one age. The inability of chondrocytes within the joint cavity to maintain homeostasis relating to these pathways favours matrix degradation and OA development. These understandings have led to renewed call for therapies that could influence and maintain appropriate chondral homeostasis (Freitag et al. 2016) and the medical community has been on the search for possible cures. In this narrative, significant strides made towards this realization are summarized.

\section{STRATEGIES FOR DIAGNOSES OF OSTEOARTHRITIS}

The diagnostic strategies include; clinical features, imaging and laboratory tests. In clinical features, the examiner does physical examination and evaluates patient's history (deformities, signs of inflammation, joint enlargement, motion limits and crepitus). Imaging is based on the expert's interpretation of pictures/film obtained via radiography, computed tomography scan, magnetic resonance imaging, ultrasonography and arthroscopy. In this, evidence of joint space narrowing, osteophyte formation, cortical bone and soft-tissue calcification, bone lost or size of subchondral cyst, superficial articular cartilage and cartilage thickness are analyzed. The laboratory testing evaluates molecular features (inflammation markers, bone markers, cartilage synthesis and degradation markers and transforming growth factor-beta degradation markers) present in the blood or urine (Kong et al. 2017).

\section{TREATMENT OPTIONS}

Basic Treatments This comprises the first line of action that evolved over the centuries. They are made up of both the non-pharmacological and pharmacological procedures. Most of the non-pharmacological procedure requires no expertise and special training to administer, compared to pharmacological procedures requires. They include various activities and applications, such as natural/physical, medical, nutritional and viscosupplementation geared towards alleviating pains of degenerating joint.

Natural/Physical Therapy These are non-pharmacological approaches which form the cornerstone of osteoarthritis management. They include activities which strengthens muscles around OA affected joints, to help ease burdens by reducing pain and likelihood of atrophy (Messier et al. 2000). Weight management helps to reduce pain and limit further damage to the joint. Specialized therapists help OA patients to learn range of motion and flexibly, massage, relaxation technique and hydrotherapy, apply heat and cold therapies and the use of assertive devices which aid function and mobility (David et al. 2016).

Medical Therapy Medical therapy constitutes of mainly the pain relievers available as pills, syrups, creams, lotions and injections. These include analgesics, non-steroidal anti-inflammatory drugs (NSAIDs) and corticosteroids. Analgesics comprised of acetaminophen, opioids (narcotics) and atypical opioids (tramadol) (MartelPelletier et al. 2015). NSAIDs constitute of the major drugs like aspirin, ibuprofen, naproxen and celecoxib (Raveendhara et al. 2015). Corticosteroid constitutes of the most potent anti-inflammatory drugs administered orally or by intra-articular injection (Jüni et al. 2015).

Nutritional Supplements Reports have advocated the role of nutriceuticals in osteoarthritis modification (McAlindon et al. 2000). From 1997, glucosamine in particular gained more popularity with the rehabilitation guidelines and it has 
been claimed that treatment with chondrotin sulfate proved long term structural-modifying effects on degenerated cartilages (Marlene et al. 2015). Other supplements include methylsulfonylmethane, collagen hydrolysate and S-adenosylmethionine (McAdams et al. 2010).

Viscosupplementation Over the years, in combination with steroid injections hyaluronic acid intra-articular injection has been used to provide temporary pain relieve in racing horses (Aroen et al. 2004). Meta-analyses on hyaluronate efficacy and safety found that moderate evidence exist to support the benefit of hyaluronate to pain reduction and functional improvement with low risk of harm (Kohn et al. 2013). Wang et al. (2007), found reduced pain from arthritis of the knee with few adverse effects. Though viscosupplementation is not commonly used in younger generations, intra-articular injections of hyaluronic acid have proved beneficial to cartilage health and repair. This illustrates the relation between increased differentiations of immature cells to chondrocytes and decreased joint inflammation (Saw et al. 2011).

Surgical Treatments A patient with OA who is not obtaining adequate pain relief and functional improvement from other non-invasive treatments is considered for surgery. The aim of contemporary surgical procedures is to achieve a more hyaline-like cartilage repair or replacement (Tuan et al. 2007). The notable surgical interventions include debridement/chondroplasty, microfracture drilling, mosaicplasty, periosteum transplantation, osteochondral autografting, osteochondral allografting, high tibial osteotomy and total knee arthroplasty (Williams et al. 2007).

Debridement/Chondroplasty This procedure cuts out damaged cartilages and reshapes the underlying healthy tissues, providing chances of regeneration (Spahn et al. 2016). This was first reported in 1946 by Magnusson et al. for injured hyaline cartilage in which, arthroscopic debridement became common for osteoarthritis patients then after. Early investigators thought that fluid flushed through the joint during this procedure, rids the knee of debris and inflammatory enzymes; but further reports changed the view. A study of 180 patients with knee osteoarthritis found that arthroscopic debridement was no more effective than placebo (Bruce et al. 2002). Other randomized controlled trials of 271 patients found no significant difference between arthroscopic debridement, lavage, closed needle lavage and placebo (McAdams et al. 2010). At present, arthroscopic debridement, offers no benefit beyond physical therapy and NSAIDs (Kenton et al. 2015)

\section{MICROFRACTURE}

This minimally invasive procedure has the goal of recruiting pluripotential stem cells from marrow, by debriding through the calcified cartilage layer followed by perforation of the subchondral bone with arthroscopic surgical awls. The preferable cartilage lesion is $1-2 \mathrm{~cm}^{2}$ (McAdams et al. 2010). In 1994, Rodrigo et al. created microfracture with an ice pick, which became popular for marrow stimulation. Functional outcomes of a study in 71 knees reported the persistence of clinical improvement, 7 years after surgery in $80 \%$ of the patients (Steadman et al. 2003). In two randomized clinical studies, Knutsen et al. (2004) found good pain relief after 2 years follow-up in $80 \%$ of patients. An improved generation of this technique has thrombogenic and adhesive polymers that increase mesenchymal stem cell recruitment and 3-dimensional organization (Mithoefer et al. 2015).

Mosaicplasty This mode of treatment is based on the harvest of plugs of cartilages from areas with relatively less weight bearing. The plugs are placed in predrilled cylinder in defects. The clinical data were first published in 1996 (Bobic et al. 1996). Furthermore clinical evaluations made on 831 mosaicplasties over a 10 years period showed $86 \%$ mean repair (Hangody \& Fule 2003). In a randomized study with about 3 years follow-up, Gudas reported superiority of mosaicplasty over microfracture in the treatment of $2.5 \mathrm{~cm}^{2}$ knee defects (Gudas et al. 2005). Mosaicplasty has been favored to microfracture, but it is only suitable for small lesions of $1-2 \mathrm{~cm}^{2}$ (Hangody \& Fule 2003).

Perichondrium/Periosteum Transplantation Since 1976, investigators has attempted perichondrium transplant to stimulate production of articular cartilage; however, two third of the grafts underwent endochondral ossification. In essence perichondrium and periosteum grafts have shown positive short term results, but the long-term clinical results remain uncertain (Tuan et al.2007). When chondrocytes are proliferated, they lose their ability to produce collagen type II and begin producing type I collagen as dedifferentiation process, but after implantation and covered by periosteum, they re-differentiate in response to local biochemical factors (Munirah et al. 2005; Ude et al. 2014). However, the re-differentiation can be hypertrophic and may pose a clinical problem.

Osteo-Chondral Autografting This procedure of harvesting bone and intact articular cartilage is specifically for osteochondritis dissecan. In a level 4 investigation, Stone et al. (2006) optimized the technique by grinding $8 \times 15 \mathrm{~mm}$ osteochondral autograft into a paste that was applied onto a $28.6 \mathrm{~cm}^{2}$ defect which showed significant improvement in pain and function. In a seven years study by Marcacci, 30 full-thickness lesions below $2.5 \mathrm{~cm}^{2}$, treated with autologous osteochondral grafts showed an average of $77 \%$ restoration of degenerated cartilages (McAlindon et al. 2000). A cohort study by Kim et al. (2012) compared the outcomes of osteochondral autograft with subchondral drilling for the first metatarsal head defect and found that osteochondral autograft restored joint functionality for defects larger than $50 \mathrm{~mm}^{2}$. 
Osteo-Chondral Allografting Segmental fresh allograft replacement of osteochondral defects was first reported by Lexar et al. (1908), but the risk of disease transmission and difficulties with procurement of fresh grafts, limited the popularity of the technique. Recipient's immune system must be suppressed to prevent rejection of graft; nevertheless, this has been employed to treat a wide spectrum of chondral injuries including, large focal chondral lesions of the knee, tibial plateau fractures, unicompartmental arthrosis of the knee and chondrosis of the patellofemoral joint (Ball et al. 2004).

High Tibial Osteotomy (HTO) This was first introduced by Jackson and Waugh in 1961 and made popular by Coventry since 1965 as a treatment modality for medial compartment osteoarthritis of the knee with varus deformity (Coventry et al. 1965). HTO is a technique suitable for young people. The goal is to shift the patient's body weight off the damaged area, to where cartilage is still healthy. A study that examined the long-term survival of closing wedge HTO in a large series of patients up to 19 years concluded that, it can be effective up to 15 years. The best outcome was found in deep lesions after thermochondroplast (Pinczewski et al. 2012).

Total Knee Arthroplasty (TKA) Knee replacement surgery is most commonly performed on older patients with advanced osteoarthritis. Fergusson was the first to report performing a resection arthroplasty of the knee in 1860; while the first synthetic implants were performed as molds fitted to femoral condyle in 1940s (Ferguson et al. 1861; Walldius et al. 1957). In 1950, the combined femoral and tibial articular surface replacements were introduced as simple hinges. Later on, in 1971, Gunston demonstrated that the knee does not rotate on a single axis like hinge; rather the femoral condyles roll and glide on the tibia with multiple directions (Gunston et al. 1971; Song et al. 2013). The highly conforming geomedic knee arthroplasty and the total condylar prosthesis were introduced in 1973; designed by Insall for special surgeries (Ranawat et al. 1976). In a long term follow-up, satisfactory knee functions were restored following TKA, and majority of patients return to low-impact sporting activity (Song et al. 2013).

Cells Therapy Cell therapy is the procedure in which cells are transplanted into patients to treat disease or modify worn out and degenerating tissue. In recent years, there has been optimism with this procedure to treat chondral defects and OA. Differentiated cells such as- chondrocytes) or stem cells can be utilized for this purpose. Stem cell is a class of undifferentiated cells that are able to differentiate into specialized cell types. Naturally, they come from two main sources, embryo and adult tissues. Apart from the tissue regenerative ability of transplanted cells, recent findings have indicated paracrine effects, which can be categorized into (trophic, immunomodulation, anti-scarring and chemo attractions) effects (Kong et al. 2017). In this, stem cells secrete a range of bioactive factors, cytokines, chemokines ligands, interleukin-6, proteases and growth factors (Freitag et al. 2016). These factors, not only attract migrating cells, but modulate the microenvironment of the damaged tissue for favourable tissue regeneration.

Autologous Cartilage Implantation (ACI) Autologous cartilage implantation involves harvesting about $300 \mathrm{mg}$ of cartilage through an arthroscopy; culturing and expanding them for about 4 weeks to get a desired number, before implantation onto lesion under a periosteum flap cover (Saris et al. 2008). This was the first cell based clinically approved application (Brittberg et al. 1994). In 1987, ACI was reported for the first time (Grande et al. 1989; Nehrer et al.2006). Brittberg et al. (1994), reported the early most encouraging work, which was approved by the US Food and Drug Administration in 1997. This use of periosteal flap, fixed to the surrounding cartilage rim to create room for the injection of cultured chondrocytes suspension was considered as the first generation. However, inherent ablations, uneven cell distributions and loss of cells into joint marred it. Hypertrophy associated with periosteal patch was the major cause of a repeat surgery and this procedure has been modified with newer techniques which combine scaffolds, cells and growth factors (Mithofer et al. 2005; Nehrer et al. 2006; Vanlauwe et al. 2012).

The matrix assisted ACI was the second generation. This technique uses a bio-absorbable collagen membrane; known as collagen-covered ACI (CACI) (Haddo et al. 2004). An important feature of this method is the incorporation of gel carrier for seeded cell to migrate to the 3-D polymer scaffold, while providing biomechanically strong environment suitable for chondrocytes maturity. However the likelihood of hypertrophic formation still remains (Tuan et al. 2007).

The third generation focused on the use of chondroprogenitor cells and bio-functionalized biomaterials for more extensive and permanent repair (Perera et al. 2012). It involves the seeding and attachment of cultured autologous chondrocytes directly onto biodegradable biomaterials reported to degrade within weeks of implantation and leaving round chondrocytes wrapped around collagen fibrils (Ehlers et al. 1999; Russlies et al. 2002). Most engineered grafts showed hyaline cartilage and the presence of viable chondrocytes; however, unevenness evidenced in matrix staining, suggests that neo-cartilage may not be homogeneous, which could compromise mechanical properties (Tuan et al. 2007).

Embryonic Stem Cells (ESCS) Ethics issues concerning the use of ESCs have been controversial. Other challenges include risk of immunorejection and tumorigenesis (Vats et al. 2006). Zur Nieden et al. (2005), demonstrated that BMP-2 can drive ESCs to chondrogenic lineage with TGF $\beta 1$, insulin and ascorbic acid identified as key signals. Vats et al. (2006) reported for the first time, that co-culture of ESC and chondrocyte can induce human ESCs towards chondrogenic lineage; furthermore, Toh et al. (2010) using a defined growth factor medium containing TGF $\beta-1$, FGF-2 
and PDGF-bb; enabled the reproducibility of chondrogenic induced human ESCs up to 16 population doublings (Zur Nieden et al. 2005). They reported a cartilage repair using hyaluronan hydrogel-encapsulated chondrogenic human ESCs. These cells were explored in osteochondral defects and the results in 12 weeks resembled age-matched unoperated native control. They also maintained long-term viability with no evidence of tumorigenicity. Various means including three-dimensional culture using BMP 2 or TGF $\beta 1$ and biophysical induction involving hypoxic or mechanical stimulations has been explored (Qu et al. 2013).

Bone Marrow Stem Cells (BMSCS) Adult stem cells, known as mesenchymal stem cell (MSC) have been introduced to repair cartilage lesions, avoiding the disadvantages of ESCs. These cells have been found to exist in different types of tissues. They are multipotent, with capability of autologous or allogeneic transplantation, because they can suppress immunity, thus evading graft versus host complications (Al Faqeh et al. 2012). Murphy et al. (2003) was among the firsts to report intra-articular injection of BMSCs to treat OA. Several other studies using similar techniques have shown promising results (Al Faqeh et al. 2012; Ude et al. $2015,2014)$. Chondrogenic differentiation, ideally occur when MSCs are cultured in three dimensional environment, serum-free medium, with the addition of TGF- $\beta$. In studies that spanned 12 years, our group has reported significant progress in using BMSCs as tool for the treatment of osteoarthritis in sheep model (Al Faqeh et al. 2012; Ude et al. 2015, 2014). Chondrogenic induced BMSCs indicated better results than uninduced (Al Faqeh et al. 2012). Long term monitoring showed articular surface filling, meniscus regeneration, biomechanical stabilization and restoration of joint function (Ude et al. 2015, 2014). Currently, the concept of injecting BMSC to treat osteoarthritis has been the subject of many clinical trials, with promising results (Kong et al. 2017).

\section{ADIPOSE DERIVED STEM CELLS (ADSCS)}

ADSCs were first termed processed lipoaspirate (PLA) cells by Zuk et al. (2002). Like BMSCs, they can differentiate toward chondrogenic lineages. It has been reported that human infrapatellar fat pad contain PLA which can be successfully harvested. They were used to treat full thickness articular cartilage and the integration of the graft was promising (Dragoo et al. 2007). Kim et al. (2009) explored more growth factors and combinations for ADSCs chondrogenesis, while Estes et al. (2010) detailed the protocols for chondrogenesis of ADSCs. Pak et al. (2011) was the first to report the regeneration of human cartilage in knee osteoarthritis with autologous ADSCs; though, the mechanism of regeneration was not clear, the MRI data for all patients showed significant positive changes for osteonecrosis of femoral head as well as osteoarthritis of the knees. Recently, we optimized a protocol for chondrogenic inductions of ADSCs; used for surgically induced OA in sheep model; the results of the biomechanical and functional analysis after 12 months showed good quality regenerated cartilages (Ude et al. 2015). We are currently on the verge of phase I/II clinical trial.

\section{UMBILICAL CORD STEM CELLS (UCSC)}

Ethical issues might apply to the use of umbilical cord stem cell therapy in certain countries. Until few years ago, blood that remained in the umbilical cord and placenta after delivery was routinely discarded. Now that it is known to contain pluripotent mesenchymal cells, there has been a substantial increase in their researches and clinical use. UCSC has decreased expression of beta-2-microglobulin, which results in reduced tissue rejection. In addition, there has been no report of their tumorigenesis (Beerheide et al. 2002). They have been shown to be efficient therapy for cartilage defects; and have properties similar to BMSCs and low immunogenicity in cartilage (Kocher et al. 2001).

Wharton's Jelly Derived Stem Cells (WJDSC) WJDSCs uniquely exhibit some of the characteristics of both MSCs and ESCs. They are positive to the MSCs markers and express lower levels of markers associated with ESCs (SSEA3, SSEA4, TRA-181, OCT-4, SOX2, Nanog) (Lim et al. 2016). They have very low immunogenicity. It has been shown that WJDSCs isolated from maternal and foetal segments possess greater viability and proliferative capacity compare to the middle segment (Kim et al. 2013; Lim et al. 2016). Poly-glycolic acid (PGA) scaffold has important effects on the chondrogenic potential of WJDSCs. This ability can be enhanced when cultured on nano-fibrous substrates, or embedded in alginate hydrogel, thus up regulating the production of hyaluronic acid, GAGs, as well as the expression of SOX9, COMP, Collagen II and FMOD (Kim et al. 2013). Most recently, Liu et al. (2017) reported that using undifferentiated WJDSCs might be better than using differentiated WJDSCs for the treatment of cartilage defects.

Peripheral Blood Mononuclear Cells (PBMCs) In this procedure, patients undergo aphaeresis, which removes some blood and extracts the desired cells (Riedhammer et al. 2016). In 2009, a preclinical study on goat model, reported that after subchondral drilling, postoperative intraarticular injections of autologous PBMCs in combination with hyaluronic acid (HA) resulted in improved cartilage repair (Saw et al. 2009). Furthermore, a pilot clinical study carried out by this same group buttressed the efficacy of articular cartilage regeneration with the combination of HA (Saw et al.2011). There has also been other works that utilized PBMCs for cartilage regenerations with positive results (Hu et al. 2011).

Gene Therapy Gene therapy involves the selection of appropriate gene and cell (chondrocytes, chondrogenic cells and cells of the synovial membrane) for gene transfer, as well as determining the optimal vector to incorporate cDNA (Gelse et al. 2003). Various viral and non-viral 
vectors are able to deliver genes to synoviocytes, articular chondrocytes and mesenchymal stem cells. The in vitro methods (which provide cells and genes) and in vivo approaches (which provide genes) can be used for articular cartilage, synovium and meniscus transfer. The in vivo method, which can target gene transfer to the synovium may be useful in chondro protection and stability; while the in vitro method which provide cells and genes can cause the regeneration of worn out cartilages (Evans et al. 2000). A successful delivery of genes into the articular cartilage was first reported in 1997 by Tomita. A haemagglutinating virus (HVJ; Sendai virus) liposome suspension containing the SV40 large T antigen (SVT) gene was used in the study. This was injected intra-articularly into the knees of rats and the post injection outcomes were impressive. Since then, there have been several similar procedures with promising results (Tomita et al. 1997).

\section{REGULATORY CHALLENGES OF REGENERATIVE THERAPY}

Translating cellular products from laboratory to bedside has been a serious issue between researchers, clinicians and regulatory bodies (Ruszymah et al. 2015). The phrase 'from bench-to-bedside' is commonly used to describe this translation; however, there are key intermediate steps in between the bench and bedside, involving governmental regulatory oversights (Knoepfler 2015). This has become more stringent as indicated by increased number of good manufacturing practice (GMP) facilities globally. While some countries adopt measures to simplify the process, others toughen the road on safety grounds (Figure 1) (Sakai et al. 2017). Human cell and tissue-based products are classified as Cell and Gene Therapy Products (CGTPs) (Malaysia, Sale of Drug Act 1952). CGTPs are considered engineered, if they undergo substantial manipulation to enhance their potentials for regeneration (Ruszymah et al. 2015). Safety, efficacy and quality of CGTPS are the main concerns of the regulatory bodies. Assays for potential microbial, fungal, endotoxin, mycoplasma and viral contamination are critical. Once these have been established, product must pass the Dry Run; which is an in vitro functional assays designed to act as surrogate measures for clinical effectiveness (Seet et al. 2013). FDA regulatory challenges pose as 'Valley of Death' because most drugs and CGTPs' developments never passed this stage (Knoepfler 2015). However, even with these, the future of cell therapy products continues to rise.

\section{DISCUSSION}

Cartilage degeneration and osteoarthritis treatments should not merely be aimed at reducing pain, but restoring degenerated structures, improving functional scores and ability to return to normal life (McAdams et al. 2010). At present, basic treatments do not avert the development of OA (Al Faqeh et al. 2012; Ude et al. 2015). Some meta-analysis found nutritional supplementation with glucosamine effective, though reaching a conclusion was difficult due to inherent commercial hype and different methods (McAlindon et al. 2000). With viscosupplementation, the

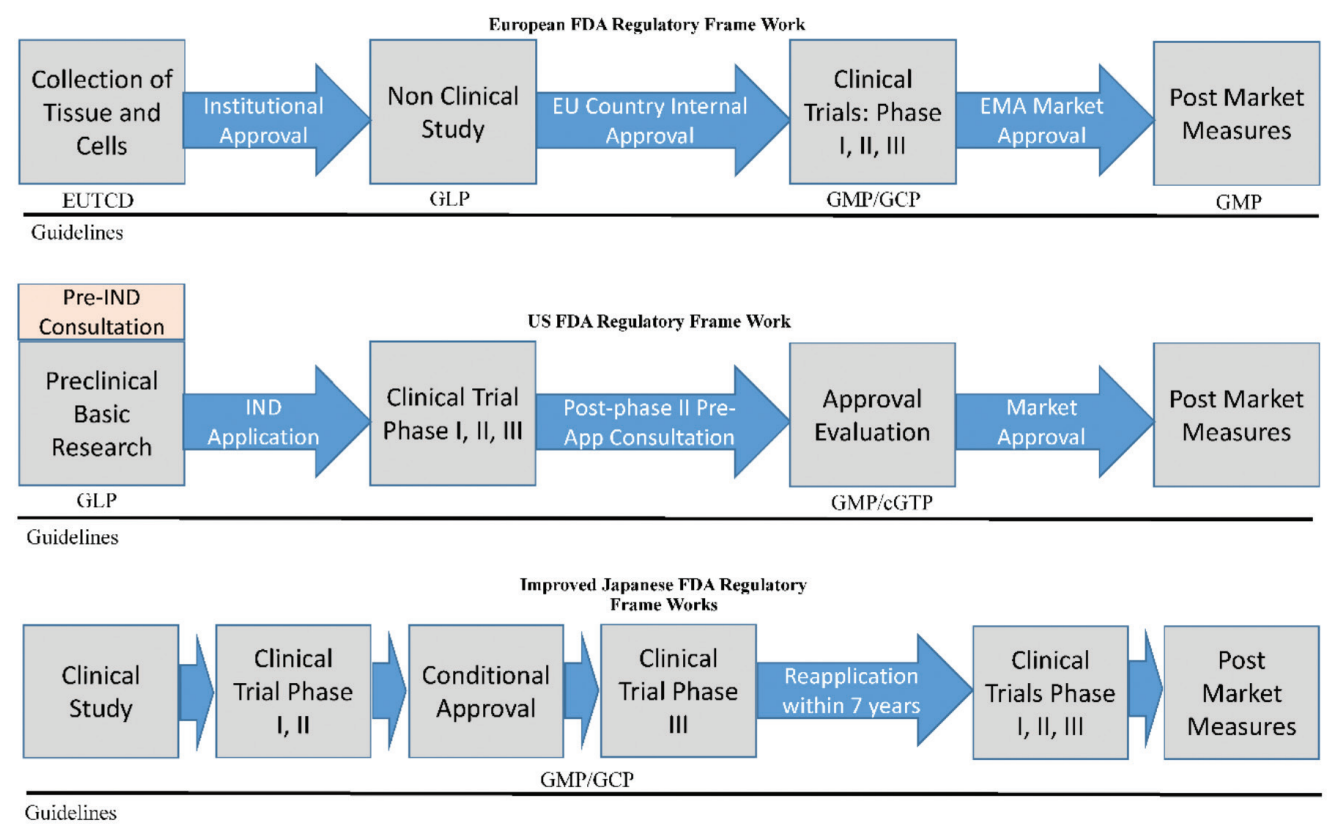

FIGURE 1. Food Drug Administration (FDA) regulatory frame work. A. Schematic overview European regulation pathway. EMA = European Medicines Agency; EU = European Union; EUTCD = European Union Tissue and Cells Directives; GCP = good clinical practice; GLP = good laboratory practice; GMP = good manufacturing practice. B. Schematic overview of United States of America regulation pathway. $\mathrm{CGTP}=$ current good tissue practice; GLP = good laboratory practice; GMP = good manufacturing practice; IND $=$ investigational new drug; App = application. C. Schematic overview of Japanese regulation pathway. GCP = good clinical practice; 
mechanism of healing remains unknown; preparations are thought to contain several growth factors that might benefit the joint. Reports showed that BMSC and hyaluronic acid have produced results consistent with hyaline cartilage but, discrepancy between studies stand as limitation (Nehrer et al. 2006). The surgical procedures, though mostly invasive and expensive, has been the most efficacious treatment for cartilage degenerations and osteoarthritis. Microfracture is considered the most used procedure with good recoveries. This could be credited to new generations of the procedure that have improved on recruitment of MSCs with more adhesion and stabilization factors (Wang et al. 2007). While some researchers reported less encouraging results from mosaicplasty, others presented more optimistic results; however, technical challenges such as periosteal flap and hypertrophy may necessitate second surgeries (McAdams et al.2010) regarding periosteum transplantation, a major limitation remains as issues with tissue availability for transplant, especially in large cartilage defects (Bobic et al. 1996).

Osteochondral autografting is reserved for patients with smaller lesions due to morbidity on large donor sites. Evidence of poor graft integration has also been a major limitation of this technique (Bobic et al. 1996). In osteochondral allografting, apart from its suitability with smaller lesions, immune suppression to prevent graft rejection has been a major issue (Mathew et al. 2016). Other-limitations include low fresh un-irradiated graft and the risk of disease transmission. The high tibial osteotomy (HTO) relieves pain in arthritis, only for a limited time. A study that examined the long-term survival of closing wedge HTO up to 19 years concluded that it can be effective for periods longer than 15 years, however, results deteriorated over time (Mathew et al. 2016). On total knee arthroplasty (TKA), it was estimated that approximately 700,000 cases are performed every year in the United States alone, with a projection of about 3.5 million in 2030 . Limitations with this procedure include: thromboembolism, infections, patellofemoral complications, neurovascular complications, periprosthetic fractures, aseptic loosening and arthrofibrosis. Nevertheless, the general death rate with TKA is well below one percent (Kurtz et al. 2007).

Cell and gene therapies are rapidly seeking translation to the clinics with promising results. Apart from safety concerns, it is also widely agreed that no standard method has been delineated for inducing stem cells into articular cartilage (Al Faqeh et al. 2012; Brittberg et al. 1994; Haddo et al. 2004; Liu et al. 2017; Ude et al. 2015). Safety issues have also been the major plague with gene therapy, owing to the use of virus as vehicle; but some studies repelled that. In a phase I clinical trial by Ha et al. (2012) on Tissue Gene-C (TG-C), a retrovirally transduced human chondrocytes expressing transforming growth factor beta-1; following a single intra-articular injection in patients with advanced knee OA, an assessment of the pharmacokinetics and biologic activity showed that it was safe for administration. The knee scoring indicated improvement of arthritic symptoms.
Appropriate regulation of CGTPs is required to ensure public safety and trust, while minimizing unnecessary barriers to product development. At present, most clinics providing stem cell therapies for osteoarthritis do not operate within the context of a formal clinical trial. Though the motives may not be outright profiteering, but attempts to help needy patients; nevertheless, the risks of harm and financial exploitations remains high. There have been efforts by various national regulatory bodies to present a blue print guiding CGTPS. The International Conference on Harmonization of Technical Requirements for Registration of Pharmaceuticals for Human Use, in its turn, has not yet finalized a standard guidelines specific to CGTPs (Seet et al. 2013). Evaluating the hypes surrounding cartilage regeneration, there still exist significant gap between promising laboratory-based research and approved CGTPS (Ruszymah et al. 2015).

\section{CRITICAL ANALYSIS}

In this concise review on approaches towards realization of cure for focal cartilage defects and osteoarthritis, the various measures of treatment utilised over the years to combat the restoration of functions to injured, degenerating or diseased articular cartilage; especially that of the knee was explored.

This narrative is both intriguing and challenging owing to the vast nature of the topic. Efforts were made towards discussing the repair, replacement and the recent regenerative approaches to cartilage degenerations and osteoarthritis.

The basic treatments (natural/physical therapy, medications, nutritional supplements and viscosupplementation) which were the earliest applications to ameliorate ensuing pains of arthritis; and still, the first line of actions in treatment were explored. Some of them, dating back from ages, need no special training for administration. The next levels, such as debridement/chondroplasty, microfracture, mosaicplasty, perichondrium/periosteum transplantation, osteochondral autografting, osteochondral allografting, high tibial osteotomy and total knee arthroplasty are mainly, the second line of treatment. They require special training and skills. The third line of treatment is the cell and gene therapy. These are the newcomers in the pursuit of cure for cartilage degeneration and osteoarthritis. They require special training and expertise. Autologous cartilage implantation, classified under this category, has evolved through different generations to overcome deficiencies of earlier versions. The majority of cellular therapies lie with the embryonic and the adult stem cells. These are currently among many ongoing clinical trials. Gene therapy develops alongside with cell therapy; both seeking for regeneration of lost cartilages with optimism.

Improvements have been made on most of these treatments, but the major shortcoming of the basic and surgical procedures is that none has regenerative capacity; nevertheless, microfracture has disease modifying as well 
as some regenerative effects. Cell therapy in the form of ACI could be regarded as surgical cell therapy; in that, its efficacy depends not only on the implanted cellular products, but also, on the skill of the surgeon. They have regenerative capacity, but their unsuitability for conditions without intact rims constitute major concerns. ESC are marred with ethical issues, samples sources and tissue rejections. Adult stem cells have received more acceptance, but are limited to proliferation and can suffer rejection in allogeneic transplant. Stem cell proliferation and differentiation capacity has been known to be age dependent; and OA mostly occur in the elderly, making allogeneic therapy more dependable as it could be provided off-the-shelf. For the gene therapy, issues concerning mutation of carriers in long term have been a major scare.

The hot topic of induced pluripotent stem cells (IPSCs), which has evolved as a substitute to ESC in proliferation and differentiations was not covered. This could have broadened the discussion, though, not without its inherent scare of instability and possible mutations. There was no mention of the use of conditioned media and biomaterials which have also been in the treatment of cartilage degenerations.

Finally, the challenges facing regeneration strategies to the clinics were highlighted. The regulations, though meant to protect the health interest of the public, can be unduly complicated and discouraging to research scientists and clinicians. Nevertheless, the authors believed that regenerative therapy, when fully in place, can give the expected cure to cartilage degeneration and osteoarthritis.

\section{FUTURE PERSPECTIVE}

One remarkable point to note is the fact that, majority of the treatments highlighted is still in use till date. Though modifications made better outcomes, but no single method has sufficed all conditions of cartilage degenerations and OA. With this in view, the future would benefit more from a combination of procedures for better treatments. More researches are needed in the regeneration procedures. The regulatory agencies should aim at streamlining their protocols; while efforts should be made to lower the cost of available therapies via mass production. This will lead to affordable combinatory treatments, for example, cell transplant and surgical modification; which could stand the chance of better regeneration and functional restoration.

\section{CONCLUSION}

Focal cartilage defect can be restored with early interventions and proper management. OA cannot be cured for now and no gold standard has been delineated. There have been significant improvements over the years, but surgical replacement remains the last option, nevertheless, other therapies are available, which can improve the quality of life and delay the need/requirement of surgical procedures/interventions.

\section{ACKNOWLEDGEMENTS}

The authors wish to acknowledge the Librarians of National University of Malaysia Medical Center and the National Defense University of Malaysia for assistance in provision of materials.

\section{REFERENCES}

Al Faqeh, H., Yahya, N.M., Chen, C.H., Saim, A.B. \& Idrus, R.B.H. 2012. The potential intra-articular injection of chondrogenic-induced bone marrow stem cells to retard the progression of osteoarthritis in a sheep model. Experimental Gerontology 47: 458-464.

Aroen, A., Sverre, L. \& Stig, H. 2004. Articular cartilage lesions in 993 consecutive knee arthroscopie. The American Journal of Sports Medicine 32(1): 211-215.

Ball, S.T., Amiel, D. \& Williams, S.K. 2004. The effect of storage on fresh human osteochondral allografts. Clinical Orthopedics and Related Research 418: 246-252.

Beerheide, W., Von Mach, M.A. \& Ringel, M. 2002. Downregulation of beta2-microglobulin in human cord blood somatic stem cells after transplantation into livers of SCID-mice: An escape mechanism of stem cells? Biochem. Biophys. Res. Commun. 294: 1052-1063.

Bobic, V. 1996. Arthroscopic osteochondral autograft transplantation in anterior cruciate ligament reconstruction: A preliminary clinical study. Knee Surg. Sports Traumatol. Arthrosc. 3: 262-264.

Brittberg, M.,Lindahl, A. \& Nilsson, A. 1994. Treatment of deep cartilage defects in the knee with autologous chondrocyte transplantation. N. Engl.J. Med. 331: 889-895.

Bruce, M.J., Kimberly, O. \& Nancy, J.P. 2002 . A controlled trial of arthroscopic surgery for osteoarthritis of the knee. N. Engl. J. Med. 347(2): 81-88.

Coventry, M.B. 1965. Osteotomy of the upper portion of the tibia for degenerative arthritis of the knee: A preliminary report. J. Bone. Joint Surg. Am. 47(5): 984-990.

David, T.F., Anthony, C.R. \& Graham, J.C. 2016. Recommendations for the conduct of efficacy trials of treatment devices for osteoarthritis: A report from a working group of the Arthritis Research UK Osteoarthritis and Crystal Diseases Clinical Studies Group. Rheumatology 55(2): 320326.

Ding, C., Cicuttini, F., Scott, F., Cooley, H., Boon, C. \& Jones, G. 2006. Natural history of knee cartilage defects and factors affecting change. Arch. Int. Med. 166: 651-658.

Dragoo, J.L., Carlson, G. \& Mccormick, F. 2007. Healing fullthickness cartilage defects using adipose-derived stem cells. Tissue Engineering 13(7): 1615-1621.

Ehlers, E-M., Fuss, M. \& Rohwedel, J. 1999. Development of a bio-composite to fill out articular cartilage lesions: Light, scanning and transmission electron microscopy of sheep chondrocytes cultured on a collagen I/III sponge. Ann. Anat. 181: 513-518.

Estes, B.T., Diekman, B.O. \& Gimbe, J.F. 2010. Isolation of adipose-derived stem cells and their induction to a chondrogenic phenotype. Nature Protocols 5(7): 1294-1311.

Evans, C.H., Ghivizzani, S.C. \& Smith, P. 2000. Using gene therapy to protect and restore cartilage. Clinical Orthopaedics \& Related Research 379: S214-S219.

Ferguson, W. 1861. Excision of the knee joint: Recovery with a false joint and a useful limb. Med. Times Gaz. 
Freitag, J., Bates, D., Boyd, R., Shah, K., Barnard, A., Huguenin, L. \& Tenen, A. 2016. Mesenchymal stem cell therapy in the treatment of osteoarthritis: Reparative pathways, safety and efficacy - A review. BMC Musculoskeletal Disorders 17: 230. doi 10.1186/s12891-016-1085-9.

Gelse, K., von der Mark, K. \& Schneider, H. 2003. Cartilage regeneration by gene therapy. Curr. Gene Ther. 3: 305-317.

Grande, D.A., Pitman, M.I. \& Peterson, L. 1989. The repair of experimentally produced defects in rabbit articular cartilage by autologous chondrocyte implantation. J. Orthop. Res. 7: $208-218$.

Gudas, R., Kelesinskas, R.J. \& Kimtys, V. 2005. A prospective randomized clinical study of mosaic osteochondral autologous transplantation versus microfracture for the treatment of osteochondral defects in the knee joint in young athletes. Arthroscopy: The Journal of Arthroscopic \& Related Surgery 21(9): 1066-1075.

Gunston, F.H. 1971. Polycentric knee arthroplasty: Prosthetic simulation of normal knee movement. J. Bone Joint Surg. Br. 53: 272-277.

Ha, C.W., Noh, M.J., Choi, K.B. \& Lee, K.H. 2012. Initial Phase I safety of retrovirally transduced human chondrocytes expressing transforming growth factor-beta- 1 in degenerative arthritis patients. Cytotherapy 14: 247-256.

Haddo, O., Mahroof, S. \& Higgs, D. 2004. The use of chondrogide membrane in autologous chondrocyte implantation. Knee 11: $51-55$.

Hangody, L. \& Fule, P. 2003. Autologous osteochondral mosaicplasty for the treatment of full thickness defects of weight bearing joints: Ten years of experimental and clinical experience. J. Bone Joint Surg. Am. 85(2): 25-32.

Hu, G., Xu, J.J., Deng, Z.H., Feng, J. \& Jin, Y. 2011. Supernatant of bone marrow mesenchymal stromal cells induces peripheral blood mononuclear cells possessing mesenchymal features. Int. J. Biol. Sci. 7(3): 364-375.

Kenton, H.F., Howard, J.H. \& Brian, C.H. 2015. State-of-the-art management of knee osteoarthritis. World J.Clin. Cases 3(2): 89-101.

Kim, D., Staples, M. \& Shinozuka, K. 2013. Wharton's Jellyderived mesenchymal stem cells: Phenotypic characterization and optimizing their therapeutic potential for clinical applications. Int. J. Mol. Sci. 14: 11692-11712.

Kim,H.J. \& Im, G.I. 2009. Chondrogenic differentiation of adipose tissue-derived mesenchymal stem cells: Greater doses of growth factor are necessary. J. Orthop. Res. 27(5): 612-619.

Kim, Y.S., Park, E.H. \& Lee, H.J. 2012. Clinical comparison of the osteochondral autograft transfer system and subchondral drilling in osteochondral defects of the first metatarsal head. Am. J.Sports Med. 40(8): 1824-1833.

Knoepfler, P.S. 2015. From bench to FDA to bedside: US regulatory trends for new stem cell therapies. Advanced Drug Delivery Reviews 82-83: 192-196.

Knutsen, G., Engebretsen, L. \& Ludvigsen, T.C. 2004. Autologous chondrocyte implantation compared with microfracture in the knee: A randomized trial. J. Bone Joint Surg. Am. 86(3): 455-464.

Kocher, A.A., Schuster, M.D. \& Szabolcs, M.J. 2001. Neovascularization of ischemic myocardium by human bone-marrow-derived angioblasts prevents cardiomyocyte apoptosis, reduces remodelling and improves cardiac function. Nat. Med. 7: 430-436.

Kohn, L., Sauerschnig, M. \& Iskansar, S. 2013. Age does not influence the clinical outcome after high tibial osteotomy. Knee Surg. Sports Traumatol. Arthrosc. 21(1): 146-151.
Kong, L., Zheng, Lz., Qin, L. \& Ho, K.K.W. 2017. Role of mesenchymal stem cells in osteoarthritis treatment. Journal of Orthopaedic Translation 9: 89e103 http://dx.doi . org/10.1016/j.jot.2017.03.006.

Kurtz, S., Ong, K. \& Lau, E. 2007. Projections of primary and revision hip and knee arthroplasty in the United States from 2005 to 2030. J. Bone Joint Surg. Am. 89(4): 780-785.

Lexar,E. 1908. Substitution of whole or half joints from freshly amputated extremities by free plastic operation. Surg Gynecol. Obstet. 6: 601-607.

Lim, J., Zainul, R.M.R. \& Law, J. 2016. MSCS can be differentially isolated from maternal, middle and fetal segments of the human umbilical cord. Cytotherapy 18 : 1493-1502.

Liu, S., Jia, Y. \& Yuan, M. 2017. Repair of osteochondral defects using human umbilical cord Wharton's jellyderived mesenchymal stem cells in a rabbit model. BioMed Research International 2017: 8760383. https://doi org/10.1155/2017/8760383.

Magnusson, P.B. 1946. Technique of debridement of the knee joint for arthritis. Surg. Clin. North Am. 26: 226-249.

Marlene, F., Maria, A. \& Lillias, N. 2015. Glucosamine and chondroitin for knee osteoarthritis: A double-blind randomized placebo-controlled clinical trial evaluating single and combination regimens. Ann. Rheum. Dis. 74: 851-858.

Martel-Pelletier, J., Camille, R. \& François, A. 2015. First-line analysis of the effects of treatment on progression of structural changes in knee osteoarthritis over 24 months: Data from the osteoarthritis initiative progression cohort. Ann. Rheum. Dis. 74: 547-556.

Mathew, A.P., Augustine, R., Kalarikkal, N. \& Thomas, S. 2016 Tissue engineering: Principles, recent trends and the future. Nanomedicine and Tissue Engineering: State of the Art and Recent Trends. New York: Apple Academic Press. pp 31-82.

McAdams, T.R., Mithoefer, K., Jason, M.S. \& Mandelbaum, B.R. 2010. Articular cartilage injury in athletes. Cartilage 1(3): 165-179.

McAlindon, T.E., LaValley, M.P. \& Gulin, J.P. 2000 Glucosamine and chondroitin for treatment of osteoarthritis: A systematic quality assessment and meta-analysis. JAMA 283: $1469-1475$.

Messier, S.P., Loeser, R.F. \& Mitchell, M.N. 2000. Exercise and weight loss in obese older adults with knee osteoarthritis: A preliminary study. J. Am. Geriatr. Soc. 48: 1062-1072.

Mithoefer, K., Lars, P. \& Marcy, Z.W. 2015. Cartilage issues in football-today's problems and tomorrow's solutions. $\mathrm{Br}$. $J$. Sports Med.49: 590-596.

Mithofer, K., Peterson, L. \& Mandelbaum, B.R. 2005. Articular cartilage repair in soccer players with autologous chondrocyte transplantation: Functional outcome and return to competition. Am. J. Sports Med.33: 1639-1646.

Munirah, S., Aminuddin, B.S., Samsudin, O.C., Chua, K.H \& Fuzina, N.H. 2005. The re-expression of Collagen II, Aggrecan and SOX9 in tissue engineered human articular cartilage. Tissue Engineering and Regenerative Medicine 2(4): 347-355.

Murphy, J.M., Fink, D.J., Hunziker, E.B. \& Barry, F.P. 2003. Stem cell therapy in a caprine model of osteoarthritis. Arthritis \& Rheumatism 48(12): 3464-3474.

Nehrer, S., Domayer, S. \& Dorotka, R. 2006. Three-year clinical outcome after chondrocyte transplantation using a hyaluronan matrix for cartilage repair. Eur.J. Radiol. 57: 3-8. 
Pak, J. 2011. Regeneration of human bones in hip osteonecrosis and human cartilage in knee osteoarthritis with autologous adipose tissue-derived stem cells: A case series. Journal of Medical Case Reports 5: 296.

Perera, J.R., Gikas, P.D. \& Bentley, G. 2012. The present state of treatments for articular cartilage defects in the knee. Annals 94(6): 381-387.

Jüni, P., Hari, R., Rutjes, A.W.S., Fisher, R., Silletta, M.G., Reichenbach, S. \& da Costa, B.R. 2015. Intra-articular Corticosteroid for Knee Osteoarthritis. Cochrane Musculoskeletal Group: John Wiley and Sons Ltd. doi: 10.1002/14651858.cd005328.

Pharmaceutical Services, Ministry of Health, Malaysia, Sale of Drug Act 1952 and Regulation. www.pharmacy.gov.my. Accessed on 22 February 2017.

Pinczewski, L., Hui, C.\& Salmon, L. 2012. Long term survival of high tibial osteotomy for medial osteoarthritis of the knee: 8to 19-year follow-up in a series of 455 patients. Orthopaedic Proceedings 94 B 29:11. doi: 10.1016/j.jsams.2010.10.471.

Qu, C., Puttonen, K.A. \& Lindeberg, H. 2013. Chondrogenic differentiation of human pluripotent stem cells in chondrocyte co-culture. Int. J. Biochem. Cell Biol. 45(8): 1802-1812.

Ranawat, C.S., Insall, J. \& Shine, J. 1976. Duo-condylar knee arthroplasty: Hospital for special surgery design. Clin. Orthop. Relat. Res. 120: 76-82.

Raveendhara, R.B., Christopher, H.S. \& David, M.K. 2015. Comparative effectiveness of pharmacologic interventions for knee osteoarthritis: A systematic review and network meta-analysis. Ann. Intern. Med. 162(1): 46-54.

Riedhammer, C., Halbritter, D. \& Weissert, R. 2016. Peripheral blood mononuclear cells: Isolation, freezing, thawing, and culture. Methods Mol. Biol. 1304: 53-61.

Rodrigo, J.J., Steadman, R.J. \& Silliman, J.F. 1994. Improvement of full thickness chondral defect healing in the human knee after debridement and microfracture using continuous passive motion. Am. J. Knee Surg. 7: 109-116.

Russlies, M., Behrens, P., Wünsch, L., Gille, J. \& Ehlers, E-M. 2002. A cell-seeded biocomposite for cartilage repair. Ann. Anat. 184: 317-323.

Ruszymah, B.H.I., Arpah, A. \& Fazillahnor, A.R. 2015. Clinical translation of cell therapy, tissue engineering and regenerative medicine product in Malaysia and its regulatory policy. Tissue Engineering: Part A 21: 23-24.

Sakai, D., Schol, J., Foldager, C.B., Sato, M. \& Watanabe, M. 2017. Regenerative technologies to bed side: Evolving the regulatory framework. Journal of Orthopaedic Translation 9: 1-7. http://dx.doi.org/10.1016/j.jot.2017.02.001.

Saris, D.B., Vanlauwe, J. \& Victor, J. 2008. Characterized chondrocyte implantation results in better structural repair when treating symptomatic cartilage defects of the knee in a randomized controlled trial versus microfracture. Am. J. Sports Med. 36(2): 235-246.

Saw, K-Y., Adam, A. \& Shahrin, M. 2011. Articular cartilage regeneration with autologous peripheral blood progenitor cells and hyaluronic acid after arthroscopic subchondral drilling: A report of 5 cases with histology. Arthroscopy: The Journal of Arthroscopic \& Related Surgery 27(4): 493-506.

Saw, K.Y., Hussin, P. \& Loke, S.C. 2009. Articular cartilage regeneration with autologous marrow aspirate and hyaluronic acid: An experimental study in a goat model. Arthroscopy 25(12): 1391-1400.

Scott, R.M., Brock, D.F., Stephanie, S.N., Rodney, D.T., Jeffre, C.W. \& Frank, A.P. 2014. Trends in the surgical treatment of articular cartilage defects of the knee in the United States. Knee Surg. Sports Traumatol. Arthrosc. 22: 2070-2075.

Seet, W.T., Ahmad, I. \& Manira, M. 2013. Quality management of a GMP laboratory for human cell and tissue therapy: Our experience in UKM Medical Centre. Regenerative Research 2(1): $50-54$

Song, E.K., Seon, J.K. \& Moon, J.Y. 2013. The evolution of modern total knee prostheses. In Arthroplasty - Update. InTech. pp. 183-195. http://dx.doi.org/10.5772/56149.

Spahn, G., Hofmann, G.O. \& Engelhardt, V.L.V. 2016. Mechanical debridement versus radiofrequency in knee chondroplasty with concomitant medial meniscectomy 10 -years result from a randomized controlled study. Knee Surg. Sports Traumatol. Arthrosc. 24(5): 1560-1568.

Steadman, J.R., Briggs, K.K. \& Rodrigo, J.J. 2003. Outcomes of microfracture for traumatic chondral defects of the knee: Average 11-year follow-up. Arthroscopy 19: 477-484.

Stone, K.R., Walgenbach, AW. \& Freyer, A. 2006. Articular cartilage paste grafting to full-thickness articular cartilage knee joint lesions: A 2- to 12-year follow-up. Arthroscopy 22: 291-299.

Toh, W.S., Lee, E.H., Guo, X.M., Chan, J.K.Y., Yeow, C.H., Choo,A.B. \& Cao, T. 2010. Cartilage repair using hyaluronan hydrogel-encapsulated human embryonic stem cell-derived chondrogenic cells. Biomaterials 31(27): 6968-6980.

Tomita, T., Hashimoto, H.\& Tomita, N. 1997. In vivo direct gene transfer into the articular cartilage by intraarticular injection mediated by HVJ (Sendai virus) and liposomes. Arthritis Rheum. 40: 901-906.

Tuan, R.S. 2007. A second-generation autologous chondrocyte implantation approach to the treatment of focal articular cartilage defects. Arthritis Research \& Therapy 9: 109. https:// doi.org/10.1186/ar2310

Ude, C.C., Ng, M.H., Chen, C.H., Htwe, O., Amaramalar, N.S., Hassan, S. \& Ruszymah, B.H.I. 2015. Improved functional assessment of osteoarthritic knee joint after chondrogenically induced cell treatment. Osteoarthritis and Cartilage 23: 1294-1306.

Ude, C.C., Sulaiman, S.B., Min-Hwei, N., Hui-Cheng, C., Ahmad, J., Yahaya, N.M.\& Ruszymah, B.H.I. 2014. Cartilage regeneration by chondrogenic induced adult stem cells in osteoarthritic sheep model. PloS One 9: 6e98770.

Vanlauwe, J.E., Claes, T. \& Van Assche, D. 2012. Characterized chondrocyte implantation in the patellofemoral joint: An up to 4-year follow-up of a prospective cohort of 38 patients. Am.J. Sports Med. 40: 1799.

Vats, A., Bielby, R. \& Tolley, N. 2006. Chondrogenic differentiation of human embryonic stem cells: The effect of the micro-environment. Tissue Engineering 12(6). https:// doi.org/10.1089/ten.2006.12.1687.

Walldius, B. 1957. Arthroplasty of the knee joint using an endoprosthesis. Acta Orthop.Scand.28: 1-112.doi: 10.3109/ ort.1957.28.suppl-24.01.

Wang, D.A., Varghese, S. \& Sharma, B. 2007. Multifunctional chondroitin sulphate for cartilage tissue-biomaterial integration. Nat. Mater. 6: 385-392.

Wayne Lee, Y-W. \& Wang, B. 2017. Cartilage repair by mesenchymal stem cells: Clinical trial update and perspectives. Journal of Orthopaedic Translation 9: $76 \mathrm{e} 88 \mathrm{http}: / / \mathrm{dx}$.doi. org/10.1016/j.jot.2017.03.005

Williams, S.K., Amiel, D.\& Ball, S.T. 2007. Analysis of cartilage tissue on a cellular level in fresh osteochondral allograft retrievals. Am. J. Sports Med. 35: 2022-2032. 
Zuk, P.A., Zhu, M. \& Peter, A. 2002. Human adipose tissue is a source of multipotent stem cells. Molecular Biology of the Cell 13: 4279-4295.

Zur Nieden, N.I., Kempka, G. \& Rancourt, D.E. 2005. Induction of chondro, osteo and adipogenesis in embryonic stem cells by bone morphogenetic protein-2: Effect of cofactors on differentiating lineages. BMC Developmental Biology 5:1 doi: 10.1186/1471-213X-5-1.

Ude Chinedu Cletus \& Azizi Miskon

Bio-artifical Organ and Regenerative Medicine Unit

National Defence University of Malaysia

Kem Sungai Besi

57000 Kuala Lumpur, Federal Territory

Malaysia
Ruszymah Bt Hj Idrus*

Department of Physiology

Medical Faculty National University of Malaysia Medical Center

Jalan Yaacob Latif, Bandar Tun Razak

56000 Kuala Lumpur, Federal Territory

Malaysia

*Corresponding author; email: ruszyidrus@gmail.com

Received: 25 March 2018

Accepted: 30 July 2018 